\title{
Modelling the relationships between the business environment, entrepreneurial orientation and employment growth amongst small, medium and micro-enterprises in South Africa
}

\begin{tabular}{|c|c|}
\hline \multicolumn{2}{|c|}{$\begin{array}{l}\text { Authors: } \\
\text { Oluwafemi J. Dele-ljagbulu }{ }^{1} \\
\text { Menisha Moos } \\
\text { Chukuakadibia Eresia-Eke }{ }^{1} \text { (1) }\end{array}$} \\
\hline \multicolumn{2}{|c|}{ 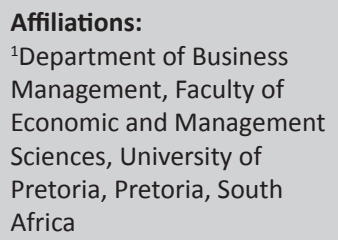 } \\
\hline \multicolumn{2}{|c|}{$\begin{array}{l}\text { Corresponding author: } \\
\text { Oluwafemi Dele-ljagbulu, } \\
\text { oluwafemi.dele-ijagbulu@ } \\
\text { up.ac.za }\end{array}$} \\
\hline \multicolumn{2}{|c|}{$\begin{array}{l}\text { Dates: } \\
\text { Received: } 09 \text { Oct. } 2020 \\
\text { Accepted: } 28 \text { May } 2021 \\
\text { Published: } 14 \text { July } 2021\end{array}$} \\
\hline \multicolumn{2}{|c|}{$\begin{array}{l}\text { How to cite this article: } \\
\text { Dele-ljagbulu, O.J., Moos, } \\
\text { M., \& Eresia-Eke, C. (2021). } \\
\text { Modelling the relationships } \\
\text { between the business } \\
\text { environment, } \\
\text { entrepreneurial orientation } \\
\text { and employment growth } \\
\text { amongst small, medium and } \\
\text { micro-enterprises in South } \\
\text { Africa. South African Journal } \\
\text { of Business Management, } \\
\text { 52(1), a2404. https://doi. } \\
\text { org/10.4102/sajbm. } \\
\text { v52i1.2404 }\end{array}$} \\
\hline \multicolumn{2}{|c|}{$\begin{array}{l}\text { Copyright: } \\
\text { (C) 2021. The Authors. } \\
\text { Licensee: AOSIS. This work } \\
\text { is licensed under the } \\
\text { Creative Commons } \\
\text { Attribution License. }\end{array}$} \\
\hline \multicolumn{2}{|l|}{ Read online: } \\
\hline 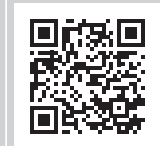 & $\begin{array}{l}\text { Scan this QR } \\
\text { code with your } \\
\text { smart phone or } \\
\text { mobile device } \\
\text { to read online. }\end{array}$ \\
\hline
\end{tabular}

Authors:

Oluwafemi J. Dele-ljagbulu ${ }^{1}$ (1) Menisha $\operatorname{Moos}^{1}$ -

Chukuakadibia Eresia-Eke ${ }^{1}$

Affiliations:

Sciences, University of

Pretoria, Pretoria, South

oluwafemi.dele-ijagbulu@

up.ac.za

How to cite this article:

Modelling the relationships

between the business amongst small, medium and micro-enterprises in South of Business Management, 52(1), a2404. https://doi. org/10.4102/sajbm is licensed under the

Creative Commons

mobile device
Purpose: This study seeks to model the nexus between environmental dynamism, environmental hostility, five sub-dimensions of entrepreneurial orientation (EO) (innovativeness, proactiveness, risk-taking, competitive aggressiveness and autonomy) and employment growth.

Design/methodology/approach: Based on a positivist research philosophy, this study adopts a quantitative methodological approach, which entails an online survey. Data is obtained through probability sampling of 1031 small, medium and micro enterprise businesses (SMMEs) and analysed using structural equation modelling (SEM).

Findings/results: The findings reveal only four dimensions namely proactive-innovation, risk-taking, competitive aggressiveness, and autonomy as statistically visible, which is contrary to five as postulated in theory. In addition, it was found that the relationships between environmental hostility, environmental dynamism and the dimensions of EO were statistically significant. Conversely, the relationships between the dimensions of EO and employment growth were statistically insignificant except within the category of medium-sized businesses (MSBs) in which proactive-innovation and competitive aggressiveness indicated a statistically significant negative association with employment growth.

Practical implications: A dynamic and hostile environment is essential to increased entrepreneurial intensity among SMMEs, but the size of the firm can be a determinant in their capacity for employment generation.

Originality/value: The association between EO and employment growth has attracted less attention in research despite its theoretical and practical significance. Furthermore, studies on the antecedents of EO such as its relationship with environmental dynamism and hostility are limited. Following a multidimensional approach to EO, this empirical study illustrates its relationship with employment growth incorporating the component of the business environment. Regarding the plausibility of these associations, it distinguishes MSBs from the other categories of businesses within the SMME cohort.

Keywords: environmental dynamism; environmental hostility; entrepreneurial orientation; employment growth; SMMEs; MSBs.

\section{Introduction}

According to Bogatyreva, Beliaeva, Shirokova and Puffer (2017, p. 338), the environment within which a business operates often stimulates its strategic behaviour. The external environment of business presents myriad opportunities, along with competition and regulation, constituting a mix that impacts its competitiveness and survival (Casillas, Moreno, \& Barbero, 2010, p. 28). Accordingly, the environment can limit exploitable opportunities available to the business and threaten its survival. In fact, the relationship between the environment and business growth is not simplistic, and the means by which firms utilise opportunities afforded by the external environment requires clarity (Futterer, Schmidt, \& Heidenreich, 2018, p. 64; Rauch, Wiklund, Lumpkin, \& Frese, 2009, p. 761). Given this complexity, the entrepreneurial orientation (EO) of a firm can be considered a critical factor because it influences strategic decision-making and overall firm competitiveness (Shirokova, Bogatyreva, Beliaeva, \& Puffer, 2016, p. 704). Furthermore, EO as a consolidated construct is empirically confirmed to have a largely positive relationship with business performance by using both financial and non-financial indicators (Al-Mamary et al., 2020, p. 200; Rauch et al., 2009, p. 761). 
However, business performance does not translate to employment growth (EG) (Neneh \& Van Zyl, 2017, p. 170), which the South African society so desperately needs. In fact, unemployment in South Africa, currently estimated at 29.1\% (Statistics South Africa, 2020), may be related to low levels of entrepreneurship across the country, along with the unpredictability, high uncertainty and the lack of competitiveness, that typify the environment within which small, medium and micro-enterprises (SMMEs) operate (Meyer \& Hamilton, 2020, p. 138; Musara, Mabila, Gwaindepi, \& Netsai, 2020, p. 1). In addition, there has been repeated emphasis on the job creation potential of SMMEs (Altinay, Madanoglu, De Vita, Arasli, \& Ekinci, 2016, p. 872), but it appears that the association between EO and EG has attracted less research attention despite its practical importance and theoretical significance (Dele-Ijagbulu, Eresia-Eke \& Moos, 2020, p. 92). Importantly, the relationship between EO and its antecedents, environment variables such as dynamism and hostility and its consequences on EG are yet to be explored adequately.

Therefore, this study seeks to elucidate the relationships between the environment, EO and EG within the context of South African SMMEs in four folds. Firstly, it studies the relationship between environmental dynamism (ED) and the dimensions of EO. Secondly, it considers the relationship between environmental hostility $(\mathrm{EH})$ and the dimensions of EO. Thirdly, it explores the relationship between the dimensions of EO, and EG for the entire SMME cohort. Fourthly, it considers this relationship across the individual categories of businesses that make up the cohort.

\section{Literature review}

\section{The environmental states of dynamism and hostility}

As exemplified in the study by Richard, Wu, Markocy and Chung (2019, p. 987), the peculiarities of dynamism within the business environment in response to strategic changes remain relevant in research. Dynamism within a business environment refers to both the uncertainty and unpredictability of future market changes and developments (Rosenbusch, Rauch, \& Bausch, 2013, p. 634). Environmental dynamism represents the magnitude and frequency of environmental change, as well as irregularity in patterns of environmental change (Richard et al. 2019, p. 992). Dynamic environments have been described as markets in which products have a short life-cycle, the level of industry innovation is high and customers' demands as well as competitors' actions are highly unpredictable (Bratnicka, 2014, p. 59). These market characteristics can apply befittingly to the small business environment in South Africa and inevitably make the environment uncertain. The uncertainty in dynamic environments may sprout from changes in customer needs, shifts in the behaviour of competitors and suppliers or technological discontinuities. Hostile environments however are characterised by precarious industry settings, intense competition, an overwhelming business climate and relative lack of exploitable opportunities (Anderson, Kreiser, Kuratko,
Hornsby, \& Eshima, 2015, p. 1580). Inevitably, this presents an unfavourable environmental condition typified by scarce resources and limited opportunities (Rosenbusch et al., 2013, p. 635). McCarthy, Puffer and Lamin (2018, p. 191) along with Bratnicka (2014, p. 61) allude to this general lack of opportunities and resources, characterised by severe regulatory restrictions, shortage of labour or raw material and decreasing markets that influence the extent to which the environment hinders sustained organisational stability and growth.

\section{Firm-level entrepreneurial orientation}

According to Lumpkin and Pidduck (2021, p. 17), EO has emerged as a core concept in the field of entrepreneurship. The concept of EO provides a useful framework for researching the intensity of entrepreneurial activities in businesses (Covin \& Wales, 2019, p. 3). Martens, Lacerda, Belfort and Freitas (2016, p. 557) observe that the EO construct fills an important gap in the literature, as the phenomenon is suitable for characterising the practice of entrepreneurship within organisations. In a seminal piece, Miller (1983, p. 775) argues that the extent to which a firm is entrepreneurial is determined by a composite weighting of three components-innovativeness (INNV), risk-taking (RT) and proactiveness (PA), which must co-vary for entrepreneurial behaviour to be established. In consequence, the conceptual formation of EO as a unidimensional construct is informed by this argument. Instructively, Lumpkin and Dess (1996) expanded the EO construct by asserting that competitive aggressiveness (CA) and autonomy (AN) are also part of what constitutes entrepreneurial characteristics, but that all EO components need not necessarily co-vary for firm-level entrepreneurial behaviour to be displayed. This position advances the idea that each EO component is distinctly reflective of entrepreneurial action. On the basis of this, the notion of $\mathrm{EO}$ as a multidimensional construct becomes tenable, and this has been reinforced by Hughes and Morgan (2007, p. 652) who consider EO as a construct comprising of five distinct variables.

As reiterated by Covin and Wales (2019, p. 4), EO refers to the processes, practices and decision-making activities that lead to new entry, with the dimensional antecedents being RT, INNV, PA, AN, and CA. Autonomy describes the independence required to conceptualise and realise a business idea, which is a critical aspect of entrepreneurial endeavour (Lumpkin, Cogliser, \& Schneider, 2009, p. 48). Innovativeness relates to the extent to which an organisation is willing to create processes, products or services, possibly to distinguish itself from competitors (Morris, Kuratko, \& Covin, 2008). Proactiveness is concerned with visionary thinking and action that allow businesses to anticipate emerging opportunities and take hold of them before the windows close (Rauch et al., 2009, p. 763). Competitive aggressiveness relates to a concerted effort to combat rivals and emerging threats in a way that allows the organisation to maintain or grow its share of the market (Lumpkin \& Dess, 1996, p. 148). The outcomes of entrepreneurial actions are often attended by uncertainty; therefore, RT focusses on a firm's inclination to explore opportunities by making 
substantial resource commitments without being discouraged by the unpredictability of the future (Eresia-Eke, DeleIjagbulu \& Moos, 2019, p. 2).

\section{The nexus of environmental states, firm innovativeness and employment growth}

Businesses operating in dynamic environments are more likely to benefit from new product innovation than those operating in stable environments (Prajogo, 2016, p. 241). Also, it has been observed that changes demanded by markets typically instigate innovation. For example, demand affects a business' disposition to develop and introduce innovations. When market demand is high or growing, businesses are more willing to invest in innovation as they perceive that there is a better chance of higher returns on such investments. In turn, these innovations increase consumer expectations and concurrently trigger competitors into responding with similar or improved innovations. In this way, growing market demand tends to stimulate INNV. Using network theory to explain the contextual background to INNV, Rodrigo-Alarcon, Gracia-Villaverde, Parra-Requena and Ruiz-Ortgea (2017, p. 559) found that a positive relationship existed between technological dynamism and the development of firm INNV. Carvalho, Rossetto and Piekas (2021, p. 1) drew a similar conclusion in their study of Brazilian start-ups. Influenced by these findings, this study elects to hypothesise that:

$\mathrm{H}_{1}$ : There is a positive relationship between ED and INNV amongst SMMEs.

Kreiser and Davis (2010, p. 39) opine that it is likely that firms operating in munificent (non-hostile) environments will be more innovative in their strategic orientation than firms operating in hostile environments. Rosenbusch et al. (2013, p. 643) stress that for a firm to perform well in hostile environments, it may be required to implement a strategic orientation characterised by low experimentation. Accordingly, INNV may be an inefficient response to hostility, but a legitimate strategic orientation in non-hostile environments. In contrast though, Li and Atuahene-Gima (2001, p. 1129) found that the turbulence in hostile environments created new market opportunities, promoted innovation and necessitated unlearning of routines for flexibility to embrace innovation. Although there is disharmony in literature as to how EH could affect INNV, the more dominant position seems to be that the relationship would be a positive one, given the number of studies that allude to this. Ceding to this position, the study proposes that in the South African SMME context:

$\mathbf{H}_{2}$ : There is a positive relationship between $\mathrm{EH}$ and INNV amongst SMMEs.

An innovation strategy is one of the most typical roads to growth as it enables new business opportunities to be explored and the firm's competitive edge to be improved (Farinha, Ferreira, \& Nunes, 2018, p. 451). Similarly, Moreno and Casillas (2008) found that a strategy of innovation had a positive and significant influence on growth. Similarly, studies have established a close association between high-growth businesses and strategic innovation (Cassia \& Minola, 2012, p. 180). Dachs and Peters (2014) examined the effect of innovation on EG in large foreign and locally owned firms and found that productinnovation contributed to EG in both types of businesses. Coad, Segarra and Teruel (2016, p. 393) found that growth in employment increased after research and development investment - if innovation resulted in higher demand and market share. Generally, there seems to be a consensus that a positive relationship exists between INNV and growth within businesses (Lumpkin \& Dess, 1996, p. 152; Rauch et al., 2009, p.775). In deference to this, the study proposes that:

$\mathbf{H}_{3}$ : There is a positive relationship between INNV and EG amongst SMMEs.

\section{The nexus of environmental states, firm proactiveness and employment growth}

Wales (2016, p. 6) notes that an entrepreneurial strategic posture makes it necessary for firms to search for new opportunities that arise in the market. As the industry conditions in a dynamic environment are subject to rapid change, businesses that are proactive and actively seek out opportunities may outperform those that are unwilling to exploit market opportunities. The earliest studies on this subject indicate that dynamic environments act to create many new opportunities and proactive strategies can be utilised to seize these opportunities and gain competitive advantage. Rosenbusch et al. (2013, p. 642) observe that the proactive introduction of new products and services makes businesses less vulnerable to the danger of obsolescence. Firms in dynamic environments can be viable in the long run only if they manage to retain a highly flexible resource base. Thus, a dynamic environment triggers the display of PA as an entrepreneurial attribute that embodies a focus on resource flexibility. Against this background, this study proposes that:

$\mathrm{H}_{4}$ : There is a positive relationship between ED and PA amongst SMMEs.

Covin and Slevin (1989, p. 76) hold the view that a proactive entrepreneurial posture may be particularly beneficial to small firms within a hostile environment. As hostility is characterised by a few opportunities and intense competitiveness, it is not unlikely that surviving firms have displayed proactive efforts. Accordingly, Miller (1983, p. 771) argues that the more hostile an environment is, the more proactive firms tend to be. However, Miller and Friesen (1983, p. 225) posit that PA can be hazardous when conditions become more demanding. The resource conservation perspective observed in hostile environments is instructive, and leaning on this perspective, Lumpkin and Dess (2001, p. 434) assert that in a hostile environment, there is increased pressure on firms thus forcing them to conserve the limited financial resources. However, this relationship could not be supported - a finding that is consistent with subsequent studies (Bogatyreva et al., 2017, p. 342). Thus, hostile environments will act to increase the level of proactive behaviour to a larger extent amongst small firms. Against this backdrop, it is hypothesised that:

$\mathbf{H}_{5}$ : There is a positive relationship between EH and PA amongst SMMEs. 
According to Lumpkin and Dess (1996, p. 146), PA relates to being the first mover amongst competitors, which can be leveraged to ensure growth. Consequently, it is considered to be an inherent attitude of a market leader, as opposed to that of a follower. In a study of young high-technology firms, Hughes and Morgan (2007, p. 656) found PA to be positively related to both product and customer performances. This amplifies the notion that PA will engender higher performance returns because it implies customer centrality. In a study of Spanish small, medium and micro-enterprises (SMEs), Casillas and Moreno (2010) found that proactive businesses in the studied population experienced higher firm growth. In a similar vein, Stenholm, Pukkinen and Heinonen's (2016) comparative study of non-family and family firms found PA to be associated with firm growth in both firm types. Rauch et al. (2009) also found PA to be associated with business performance. Duly cognisant of these findings in the extant literature, this study elects to hypothesise that:

$\mathbf{H}_{6}$ : There is a positive relationship between PA and EG amongst SMMEs.

\section{The nexus of environmental states, firm risk- taking and employment growth}

Dynamism in the environment may be associated with organisational RT as businesses that are risk-averse under such conditions lose market share and will not be able to maintain a strong industry standing relative to their risktolerant counterparts (Lumpkin \& Dess, 1996, p. 152). Gilley, Walters and Olson (2002, p. 104) confirmed the role of dynamism in top management RT, although they found that the benefit of RT was reduced in more dynamic environments. Nonetheless, Kreiser and Davis (2010) insist that organisations need to make bold, risky strategic decisions to cope with the constant state of change in dynamic environments to improve business performance. This assertion lends credence to the thinking that organisational RT could be more positively associated with business performance in dynamic environments relative to stable environments. Cognisant of this, the study hypothesises that:

$\mathbf{H}_{7}$ : There is a positive relationship between ED and RT amongst SMMEs.

According to Kreiser, Anderson, Kuratko and Marino (2020), the relationship between EH and RT is unclear. Whilst extremely munificent environments may not provide firms with an impetus to take risks, it is reasonable to contend that excessively hostile environments would discourage organisations from taking risks. Goll and Rasheed (1997, p. 583 ) opined that the lack of resources in hostile environments would lead firms to avoid excessive RT and pay greater attention to the conservation of resources. According to Kreiser et al. (2020), this perspective has been informed largely by the concept of threat-rigidity, which argues that organisations will respond to threatening situations by lessening their emphasis on RT. At the same time, munificent environments will act to discourage organisational RT because organisations in such environments can employ typically more conservative strategies and still remain profitable (Covin \& Slevin, 1989, p. 77). Hence, this study is cognisant of the position of previous studies and mindful of the contextual nature of relationships in the business environment. Indeed, within the specific context of South Africa, characterised by uncertainties of a consequential nature, this study opts to hypothesise that:

$\mathbf{H}_{\mathbf{g}}$ : There is a positive relationship between EH and RT among SMMEs.

Arguments in favour of a positive relationship between risk and return are not uncommon. As observed by Lumpkin and Dess (1996, p. 144), firms with an EO are often typified by RT behaviour. Lotz and Van der Merwe (2013, p. 19) attested to the obscurity of the relationship between RT and firm growth by elaborating on Wiklund and Shepherd's (2005) argument that whilst conservative positions in strategic choices may lead to high performance, risky strategies may result in performance variation because inherently some projects are prone to failure whilst others to success. Interestingly, Naldi, Nordqvist, Sjoberg and Wiklund (2007) found that amongst Swedish family firms, entrepreneurial RT is negatively related to performance. In contrast, Fairoz and Hirobami (2016) found a positive relationship between RT and performance amongst SMEs in Japan. Similarly, Ahmed and Brennan (2019, p. 389) also found a positive relationship between RT propensity and the degree of export, which is indicative of higher performance levels. Mindful of these findings, this study is inclined towards the viewpoint that:

$\mathrm{H}_{9}$ : There is a positive relationship between RT and EG amongst SMMEs.

\section{The nexus of environmental states, firm competitive aggressiveness and employment growth}

According to Lumpkin and Dess (1996, p. 148), CA requires firms to challenge their competitors directly and intensely to achieve entry or improve their positions. This entails the display of a combative and forceful approach towards rivals through pre-emptive actions and aggressive responses (Lumpkin \& Dess, 2001, p. 433). Presumably, small businesses in South Africa adopt this leaning, given the fact that they operate in a dynamic environment replete with changes (Maziti, Chinyamurindi, \& Marange, 2018, p. 368). Strangely though, Lumpkin and Dess (2001, p. 437) also argue that CA is consistent with exploitation; however, it is more feasible in stable environments than in dynamic settings. Nadkarni, Chen and Chen (2016) examined the relationship between industry velocity CA and firm performance and found that it positively affected performance in a stronger manner in high-velocity industries compared with low-velocity industries. This finding makes this study propose that:

$\mathbf{H}_{10}$ : There is a positive relationship between ED and CA amongst SMMEs.

Given the paucity of product-market opportunities and the need to defend industry position vigorously in hostile environments, small firms often realise their goals only through aggressive stances (Khedhaouria, Gurau, \& Torres, 
2015, p. 485). Although reluctant to assume the challenges associated with CA in hostile environments, they may not be able to survive otherwise. Indeed, Covin and Slevin (1989, p. 81) found that small firms in hostile environments generally performed best when they demonstrated a high level of CA. Lumpkin and Dess (2001, p. 437) opined that the discipline required to compete successfully in a hostile environment would be consistent with a competitively aggressive posture, and their hypothesis, which postulates a positive relationship between the two, was found to be supported. In consideration of this, it is therefore hypothesised that:

$\mathrm{H}_{11}$ : There is a positive relationship between $\mathrm{EH}$ and CA amongst SMMEs.

Lumpkin and Dess (2001, p. 431) observe that CA has been investigated less frequently; therefore, not much is known about its association with firm growth and performance. Nonetheless, Casillas and Moreno (2010, p. 281) found no relationship between CA and firm growth possibly because it is merely a reactive behaviour towards competitors in defence of a market position. Le Roux and Bengesi (2014, p. 609) concur that CA merely implies a tendency to challenge competitors to achieve entry or outperform industry rivals in the marketplace. This corroborates the notion that CA is more of a response to rivals' competitive threats than a posture to defend a firm's own competitive advantage. Furthermore, Yang and Ju (2018, p. 128) investigated both strategies, PA and CA, and found that CA was useful mainly for large firms and exclusively at the initial stages of the firm's evolutionary path. This argument influences the formulation of the hypothesis that:

$\mathrm{H}_{12}$ : There is a negative relationship between CA and EG amongst SMMEs.

\section{The nexus of environmental states, firm autonomy and employment growth}

Autonomy connotes the independence of actions and decision-making by individuals or teams towards bringing forth a concept or vision and carrying it through to completion (Lumpkin \& Dess, 2001, p. 431). Autonomy is more of a catalyst to entrepreneurial activity (Alexandrova, 2004, p. 140), as it affords organisational members the freedom and flexibility to develop and enact entrepreneurial initiatives. It is the independent spirit that seeks the freedom to explore new opportunities by taking risks to create new ventures. However, entrepreneurial individuals and teams could not operate in this manner without an environment that promotes independent economic behaviour and opportunity-seeking actions (Lumpkin et al., 2009, p. 49). Much of this could be more feasible in a dynamic environment, which is subject to rapid changes and possesses a higher propensity for opportunities than stable environments. Hence, in this study, it is hypothesised that:

$\mathbf{H}_{13}$ : There is a positive relationship between $\mathrm{ED}$ and $\mathrm{AN}$ amongst SMMEs.

Kusumawardhani, McCarthy and Perera (2009) argue that when employees are given the leverage of independence in decision-making, they will be sensitised to act entrepreneurially and thus will help to enhance the performance of the business. Lumpkin and Dess (1996, p. 140) described AN as the ability and the will to be self-directed in the pursuit of opportunities and emphasised it as a key dimension of entrepreneurial action. These actions may be necessary to gain a competitive advantage in the precarious setting of a hostile environment. Indeed, the fast-paced turbulence that may be characteristic of hostile environments may encourage organisations to empower their employees to take expedited actions that could contribute to continued organisational operations rather than confront the ramifications of delays arising from bureaucratic decision processes. Although cognisant of the position of other researchers as presented in this section, this argument encourages the study to contend that:

$\mathrm{H}_{14}$ : There is a positive relationship between $\mathrm{EH}$ and $\mathrm{AN}$ amongst SMMEs.

Moreno and Casillas (2007) argue that the ability of SMEs to enter into agreements with other firms that allow the SMEs the use of resources and capacities without the burden of owning them engenders SME growth. Brock (2003, p. 66) supports the view that $\mathrm{AN}$ encourages innovation, promotes the launching of entrepreneurial ventures and increases the competitiveness of firms. In contrast, firms that are overly dependent on collaboration in decision-making and require consensus to be reached before launching entrepreneurial initiatives may suffer financially (Covin, Green, \& Slevin, 2006, p. 57). Based on these arguments, researchers tend to defend a positive relationship between $\mathrm{AN}$ and firm growth (Casillas \& Moreno, 2010, p. 265), a stance which is also supported by Lotz and Van der Merwe (2013, p. 26). Hence, this study hypothesises that:

$\mathbf{H}_{15}$ : There is a positive relationship between AN and EG amongst SMMEs.

The hypothesised relationships identified are reflected in the conceptual model for this study as presented in Figure 1. In addition, it depicts the interconnection between ED, EH, EO and EG.

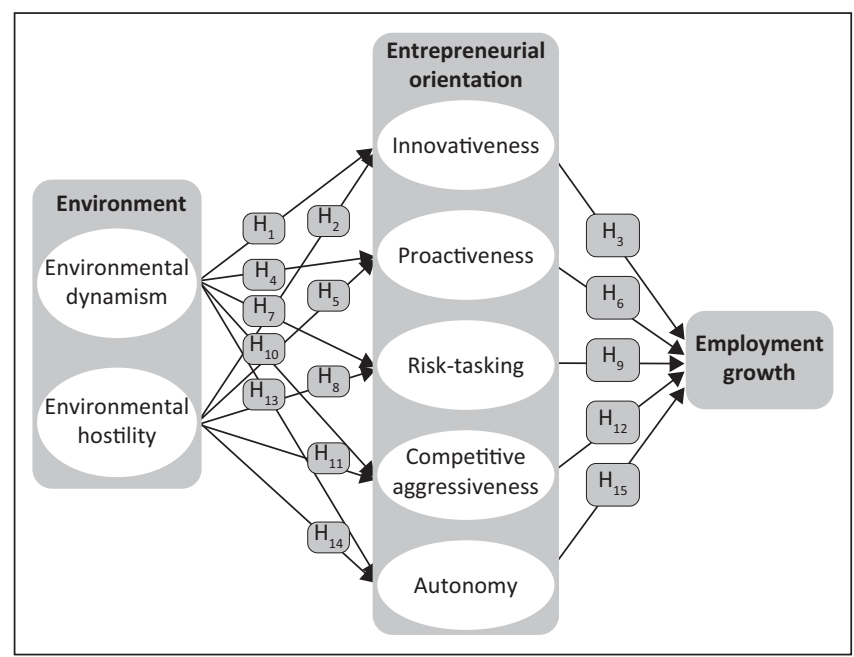

FIGURE 1: Conceptual model of the study. 


\section{Methodology}

A quantitative methodological approach, which is not uncommon in EO research, was espoused in this study. As seminal studies on the construct have largely carried out the same (see Lumpkin \& Dess, 1996; Rauch et al., 2009; Wales, 2016), this affords a logical basis for comparison. Fundamentally, the research pathway of this study aligns with a deductive reasoning process, which according to Cooper and Schindler (2014, p. 126) purported to be conclusive, leveraging on precursory reasons provided. The study focusses on the individual components of EO as predictors of EG, implying that it is a causal explanatory study. The study entailed an online survey of SMMEs across the nine provinces of South Africa. A simple random probability sampling technique was employed to identify and select respondents from the databases of governmental agencies, such as the Small Enterprise Development Agency and the Sector Education Training Authorities. Over a 2-month period, 2230 self-administered questionnaires were emailed to SMMEs. The responding firms are categorised based on economic sector, phase of business operation and total annual turnover as presented in Table 1.

In this study, EG is considered as the increase in the number of employees, and so a selective process was utilised to retain only the businesses that showed positive growth, leaving 1031 responses for analysis, which equates to an effective response rate of $46.2 \%$. To enable the investigation of the study's constructs, previously used and validated instruments developed by Hughes and Morgan (2007), Miller and Friesen (1982) and Slevin and Covin (1997) were employed for the measurement of EO, ED and $\mathrm{EH}$, respectively. Employment growth is assessed objectively with the use of Gibrat's (1931) original law of proportionate effect, which assumes that the growth rate of a firm is constant and is mathematically expressed as:

$S_{1}=S_{0}(1+G)^{T_{1}-T_{0}}$

[Eqn 1]

where:

$\mathrm{T}_{1}$ is the current year of operation;

$\mathrm{T}_{0}$ is the firm's birth year;

$\mathrm{S}_{1}$ is the current number of employees;

$\mathrm{S}_{0}$ is the number of employees at the firm's birth; and

$\mathrm{G}$ is the annual growth rate of the number of employees.

TABLE 1: Sample characteristics $(n=1031)$

\begin{tabular}{llcc}
\hline Variable & Characteristic & $\boldsymbol{n}$ & $\mathbf{\%}$ \\
\hline Economic sector & Service-based firms & 439 & 42.6 \\
& Non-service-based firms & 592 & 57.4 \\
Phase of business & Start-ups (< 3.5 years in operation) & 48 & 4.7 \\
operation & Established ( $\geq 3.5$ years in operation) & 983 & 95.3 \\
Total annual & $\leq$ R3 000 000 & 452 & 43.8 \\
turnover & R3 000 000 to R6 000 000 & 146 & 14.2 \\
& R6 000 000 to R10 000 000 & 80 & 7.8 \\
& R10 000 000 to R14 000 000 & 75 & 7.3 \\
& R14 000 000 to R26 000 000 & 121 & 11.7 \\
& $\geq$ R26 000 000 & 157 & 15.2 \\
\hline
\end{tabular}

Responses were extracted from returned questionnaires and were then coded. Subsequently, inferential statistical techniques were used to analyse the data because the primary objective of the study is to test the hypotheses. Therefore, exploratory factor analysis was conducted to ascertain construct validity, SEM and Pearson product-moment correlation analysis were employed to test the relationships between the variables as hypothesised in the study.

\section{Presentation of findings Descriptive statistical analysis}

Descriptive analysis of the data profiles the SMMEs according to economic sector, phase of business operation and total annual turnover. As presented in Table 1 the sample considered comprised $57.4 \%$ non-service-based businesses and $42.6 \%$ service-based businesses. According to Singer, Amorós, Arreola and the Global Entrepreneurship Research Association (2015) in the Global Entrepreneur Monitor (GEM) Report, businesses that have been in operation for at least 3.5 years are classified as established; otherwise, they are characterised as start-ups. Accordingly, 95.3\% of businesses that participated in the study fall within the established business category. Implicitly, the sample consists largely of businesses that have stemmed the tide of the 'liability-of-newness' that often overwhelms start-up ventures. This means that respondents may be well informed of the EO and EG of their firms and the environment in which they operate. Furthermore, these businesses have transitioned into the growth phase, which according to Singer et al. (2015, p. 23) is a reflection of prior entrepreneurial action, and this indicates that they possibly embody an effective EO. Characteristic of the small business environment in South Africa, 452 (43.8\%) of businesses in the study's valid sample had a total annual turnover under R3 000000.

\section{Exploratory factor analysis}

In assessing the measurement model through exploratory factor analysis (EFA), the specific items in the instrument measuring the dimensions of ED, EH, EO and EG were extracted by using principal axis factoring (PAF) and varimax rotation. Because factor extraction involves determining the smallest number of factors that can be used to best represent the interrelationships amongst the set of variables (Pallant, 2011, p. 183), rotation is necessary as it presents the underlying loading patterns distinctly. Table 2 shows the rotated factor matrix. Prior to that, Kaiser-Meyer-Olkin (KMO) test for sampling adequacy and Bartlett's test of sphericity, which assesses the suitability of the data for factor analysis, were conducted. The KMO and Bartlett's test values were 0.919 and 11170.793 , respectively. These values are statistically significant given the $p$-value of 0.000 , which implied the suitability of the data for EFA as indicated by Pallant (2011, p. 183).

The items measuring the eight individual variables of the study were analysed together. However, the items were loaded into seven variables as shown in Table 2. Proactiveness (PA1 to PA3) and innovativeness (INNV1 to INNV3) were 
TABLE 2: Exploratory factor analysis results for measurement model.

\begin{tabular}{|c|c|c|c|c|c|c|c|c|}
\hline \multirow[t]{2}{*}{ Question number } & \multirow[t]{2}{*}{ Indicator items } & \multicolumn{7}{|c|}{ Rotated factor matrix $\dagger$} \\
\hline & & 1 & 2 & 3 & 4 & 5 & 6 & 7 \\
\hline Q1.1 & RT1 & 0.241 & 0.155 & 0.158 & 0.170 & $0.621 *$ & 0.042 & 0.081 \\
\hline Q1.2 & $\mathrm{RT} 2$ & 0.335 & 0.177 & 0.121 & 0.072 & $0.792^{*}$ & 0.038 & 0.052 \\
\hline Q1.3 & RT3 & 0.489 & 0.217 & 0.084 & 0.041 & $0.555^{*}$ & 0.139 & 0.033 \\
\hline Q1.4 & INNV1 & $0.757^{*}$ & 0.141 & 0.023 & 0.065 & 0.181 & 0.147 & -0.025 \\
\hline Q1.5 & INNV2 & $0.814 *$ & 0.200 & 0.026 & 0.064 & 0.161 & 0.136 & 0.004 \\
\hline Q1.6 & INNV3 & $0.817^{*}$ & 0.188 & 0.075 & 0.059 & 0.149 & 0.113 & -0.001 \\
\hline Q1.7 & PA1 & $0.675^{*}$ & 0.204 & 0.122 & 0.305 & 0.150 & 0.003 & 0.031 \\
\hline Q1.8 & PA2 & $0.635^{*}$ & 0.170 & 0.041 & 0.370 & 0.104 & -0.027 & -0.006 \\
\hline Q1.9 & PA3 & $0.558^{*}$ & 0.179 & 0.013 & 0.422 & 0.091 & 0.031 & 0.002 \\
\hline Q1.10 & CA1 & 0.316 & 0.075 & 0.385 & $0.527^{*}$ & 0.104 & 0.034 & -0.027 \\
\hline Q1.11 & CA2 & 0.412 & 0.122 & 0.153 & $0.739 *$ & 0.157 & -0.031 & -0.027 \\
\hline Q1.12 & CA3 & 0.331 & 0.192 & 0.209 & $0.664 *$ & 0.105 & -0.038 & -0.008 \\
\hline Q1.13 & AN1 & 0.208 & $0.746^{*}$ & 0.024 & 0.110 & 0.077 & -0.024 & 0.083 \\
\hline Q1.15 & AN3 & 0.124 & $0.828^{*}$ & 0.029 & 0.042 & 0.062 & 0.025 & 0.057 \\
\hline Q1.16 & AN4 & 0.115 & $0.747^{*}$ & 0.110 & 0.070 & 0.094 & 0.007 & -0.064 \\
\hline Q1.17 & AN5 & 0.094 & $0.787^{*}$ & 0.069 & 0.093 & 0.104 & 0.096 & -0.044 \\
\hline Q1.18 & AN6 & 0.113 & $0.514^{*}$ & 0.072 & 0.053 & 0.075 & 0.096 & -0.125 \\
\hline Q2.1 & $\mathrm{EH} 1$ & 0.039 & 0.103 & $0.561 *$ & -0.035 & 0.128 & 0.154 & -0.037 \\
\hline Q2.2 & $\mathrm{EH} 2$ & 0.078 & 0.087 & $0.594 *$ & -0.007 & 0.041 & 0.109 & -0.023 \\
\hline Q2.3 & $\mathrm{EH} 3$ & 0.074 & 0.028 & $0.624 *$ & 0.080 & 0.060 & 0.039 & -0.035 \\
\hline Q2.4 & $\mathrm{EH} 4$ & -0.020 & 0.000 & $0.512 *$ & 0.080 & 0.042 & 0.066 & 0.178 \\
\hline Q2.5 & EH5 & 0.087 & 0.021 & $0.718^{*}$ & 0.140 & 0.033 & -0.056 & 0.126 \\
\hline Q2.6 & EH6 & -0.031 & 0.035 & $0.608 *$ & -0.015 & -0.011 & -0.032 & 0.124 \\
\hline Q3.1 & ED1 & 0.177 & 0.020 & 0.206 & 0.116 & 0.106 & $0.358^{*}$ & 0.179 \\
\hline Q3.2 & ED2 & 0.054 & 0.037 & 0.166 & 0.027 & 0.010 & $0.580 *$ & 0.120 \\
\hline Q3.3 & ED3 & -0.003 & -0.022 & 0.161 & 0.056 & 0.030 & $0.225^{*}$ & 0.568 \\
\hline Q3.4 & ED4 & -0.015 & -0.003 & 0.132 & 0.040 & 0.074 & $0.246^{*}$ & 0.515 \\
\hline Q3.5 & ED5 & 0.097 & 0.063 & -0.054 & -0.041 & 0.030 & $0.491 *$ & 0.187 \\
\hline
\end{tabular}

Note: Extraction method: principal axis factoring; rotation method: Varimax with Kaiser normalisation

$\dagger$, Rotation converged in seven iterations.

*, indicates how the factors converged. These loadings have notably higher values than those of the same column.

Q, Question; RT, risk-taking; INNV, innovativeness; PA, proactiveness; CA, competitive aggressiveness; AN, autonomy; EH, environmental hostility; ED, environmental dynamism; EG, employment growth.

loaded as a single factor, indicative of one combined variable. This is a distinct finding that indicates a strong association between PA and INNV leading to convergence. As expected, the other variables, RT items (RT1 to RT3) and the CA items (CA1 to CA3), were loaded as separate factors, which was the same for the items measuring AN (A1 to A6). The items measuring ED (ED1 to ED5) and $\mathrm{EH}$ (EH1 to EH6) were loaded as two separate factors, confirming these as different variables. Notably, two of the items (ED3 and ED4) showed comparatively lower loadings. Hence, they were excluded from further analysis based on the minimum value of 0.35 as adopted by Lotz and Van der Merwe (2013). The analysis also revealed that EG indicated by the annual growth rate of employees $(G)$ were loaded separately as one variable.

This study's EFA results indicate that the respondents to this study were unable to distinguish between the factors of 'innovativeness' and 'proactiveness', as it was perceived as a single variable. This finding is not unduly alarming as studies by Neneh and Van Zyl (2017) and Matchaba-Hove and Goliath (2016), which examined the components of EO amongst SMEs in South Africa, found similar results. In addition, Soininen, Martikainen, Puumalainen and Kyläheiko (2012) examined the dimensionality of EO and found that the items measuring INNV and PA also merged into a single component.

Accordingly, Anderson et al. (2015), attempted to reconceptualise $\mathrm{EO}$ and suggested the existence of a positive co-variance between INNV and PA. According to Shafaeddin (2012, p. 166), 'proactive-innovation' refers to an innovation approach in which a firm continually delineates new opportunities and challenges by proactively seeking different perspectives, generating ideas for new products, services, solutions and commercialising innovations far ahead of their followers.

In the light of these arguments and the EFA results obtained in this study, it would therefore seem conceptually inconsistent to create a theoretical distinction between PA and INNV. Consequently, rather than have PA and INNV as independent constructs, this study considers them as a single dimension of EO. As innovativeness and proactiveness are loaded as one factor, it will be subsequently referred to as 'proactive-innovation' (P-INNV), following the precedence of Neneh and Van Zyl (2017, p. 172). This necessitates a restatement of the hypotheses that are based on these two EO dimensions. 
Hence, hypothesis $H_{1}, H_{2}, H_{3^{\prime}} H_{4^{\prime}} H_{5}$ and $H_{6}$ are restated as $H_{1 \& 4} H_{2 \& 5}$ and $H_{3 \& 6}$ :

$\mathrm{H}_{1 \& 4}$ : There is a positive relationship between ED and proactiveinnovation amongst SMMEs.

$\mathrm{H}_{2 \& 5}:$ There is a positive relationship between $\mathrm{EH}$ and proactiveinnovation amongst SMMEs.

$\mathbf{H}_{3 \& 6}$ : There is a positive relationship between proactiveinnovation and EG amongst SMMEs.

\section{Examination of hypothesised relationships}

The study utilised structural equation modelling (SEM) analysis to interrogate the existence (or lack thereof) of a relationship between ED and the individual EO dimensions. The results of the analysis are presented in Table 3. Examining the relationship between ED and P-INNV, RT, CA and AN, the $p$-values were found to be $0.000,0.000,0.001$ and 0.005 , respectively. As all values are less than $0.05(p<0.05)$, statistical significance is confirmed, and hence $H_{1 \& 4^{\prime}} H_{7^{\prime}} H_{10}$ and $H_{13}$ were found to be supported. On the basis of the empirical evidence, the study argues that amongst SMMEs in South Africa, ED has a positive relationship with all dimensions of EO.

Similarly, through SEM analysis, the existence of (or a lack thereof) a relationship was interrogated between $\mathrm{EH}$ and the individual EO components. Examining the relationship between EH and P-INNV, RT, CA and AN, the $p$-values were found to be $0.003,0.000,0.000$ and 0.000 , respectively. As all values are less than $0.05(p<0.05)$, statistical significance is also confirmed, and hence $H_{2 \varepsilon 5^{\prime}} H_{8^{\prime}} H_{11}$ and $H_{14}$ were found to be supported. On the basis of the empirical evidence, the

TABLE 3: Results of structural equation modelling

\begin{tabular}{llcccc}
\hline $\begin{array}{l}\text { Hypothesised } \\
\text { relationship }\end{array}$ & $\begin{array}{l}\text { Associated } \\
\text { hypothesis }\end{array}$ & $\begin{array}{c}\text { Path co- } \\
\text { efficient }\end{array}$ & t-statistic & $\boldsymbol{p}$ & $\begin{array}{c}\text { Hypothesis } \\
\text { decision }\end{array}$ \\
\hline ED $\rightarrow$ P-INNV & $\mathrm{H}_{184}$ & 0.234 & 7.249 & 0.000 & Supported \\
ED $\rightarrow$ RT & $\mathrm{H}_{7}$ & 0.203 & 6.273 & 0.000 & Supported \\
$\mathrm{ED} \rightarrow \mathrm{CA}$ & $\mathrm{H}_{10}$ & 0.101 & 3.225 & 0.001 & Supported \\
$\mathrm{ED} \rightarrow \mathrm{AN}$ & $\mathrm{H}_{13}$ & 0.095 & 2.832 & 0.005 & Supported \\
$\mathrm{EH} \rightarrow \mathrm{P}-\mathrm{I} N \mathrm{NNV}$ & $\mathrm{H}_{285}$ & 0.111 & 2.974 & 0.003 & Supported \\
$\mathrm{EH} \rightarrow \mathrm{RT}$ & $\mathrm{H}_{8}$ & 0.193 & 5.715 & 0.000 & Supported \\
$\mathrm{EH} \rightarrow \mathrm{CA}$ & $\mathrm{H}_{11}$ & 0.350 & 11.390 & 0.000 & Supported \\
$\mathrm{EH} \rightarrow \mathrm{AN}$ & $\mathrm{H}_{14}$ & 0.127 & 3.491 & 0.000 & Supported \\
\hline
\end{tabular}

$\mathrm{ED}$, environmental dynamism; EH, environmental hostility; RT, risk-taking; $\mathrm{AN}$, autonomy; ED, environmental dynamism; EH, environmental hostit
CA, competitive aggressiveness; INNV, innovativeness. study argues that amongst SMMEs in South Africa, EH has a positive relationship with all the dimensions of EO. On the basis of these results, the study provides empirical evidence that $\mathrm{EH}$ has a positive relationship with all the components of EO amongst SMMEs.

Table 4 presents the results of the correlation analysis carried out to examine the study's hypothesised relationships between EO dimensions and EG, for all categories of SMMEs. The results reveal that a statistically significant relationship cannot be confirmed between any of the dimensions (PA-INNV, RT, CA and AN) and EG. Therefore, hypotheses $H_{3 \varepsilon^{\prime}}, H_{9}, H_{12}$ and $H_{15}$ have not been supported because their associated $p$-values are statistically insignificant $(p>0.05)$ at a $95 \%$ confidence level. Although support could not be found for the hypotheses that examined the relationship between the dimensions of EO and EG for all SMMEs, the study went further to investigate the hypothesised relationships, within the four categories of SMMEs (micro-, very small-, small- and medium-sized businesses [MSBs]). As shown in Table 4, amongst MSBs, a statistically significant association was found between PAINNV and EG and between CA and EG with $p$-values of -0.235 and -0.229 , respectively. This implies that in the cohort of MSBs exclusively, the hypothesised relationship between CA and EG $\left(H_{12}\right)$ is supported, and the relationship between PA-INNV and EG $\left(H_{3 \& 6}\right)$, although not supported, is statistically significant. Interestingly, this finding amongst MSBs differs from that of Altinay et al. (2016), possibly because they did not investigate the existence (or lack) of the relationship of interest within specific cohorts of SMMEs. This argument is tenable given that this study's finding aligns with Neneh and Van Zyl's (2017) study of MSBs.

\section{Theoretical models for environment, entrepreneurial orientation and employment growth}

Although a conceptual model is shown in Figure 1, in view of the findings of this study and the inferences drawn with regard to the hypothesised relationships, changes to this model have been made to reflect this. Consequently, theoretical models are presented in this section to illustrate the nexus of environment, EO dimensions and EG. These models indicate which of the hypothesised relationships found support from the sample considered in this study.

TABLE 4: Results of correlation analysis for the categories of small, medium and micro-enterprises.

\begin{tabular}{|c|c|c|c|c|c|c|}
\hline Categories & Indicator & Variable & RT & PA-INNV & CA & AN \\
\hline \multirow{2}{*}{ All SMMEs $n=1031$} & \multirow[t]{2}{*}{ EG } & Pearson correlation & 0.006 & 0.018 & 0.032 & 0.019 \\
\hline & & Sigma (2-tailed) & 0.851 & 0.571 & 0.305 & 0.544 \\
\hline \multirow{2}{*}{ Micro ( 1 to 5 employees) $n=322$} & \multirow[t]{2}{*}{ EG } & Pearson correlation & 0.021 & 0.018 & -0.011 & 0.040 \\
\hline & & Sigma (2-tailed) & 0.706 & 0.747 & 0.844 & 0.472 \\
\hline \multirow{2}{*}{ Very small ( 6 to 10 employees) $n=227$} & \multirow[t]{2}{*}{ EG } & Pearson correlation & -0.064 & -0.062 & -0.093 & -0.044 \\
\hline & & Sigma (2-tailed) & 0.340 & 0.352 & 0.163 & 0.512 \\
\hline \multirow{2}{*}{ Small (11 to 50 employees) $n=348$} & \multirow[t]{2}{*}{ EG } & Pearson correlation & 0.081 & 0.014 & 0.035 & 0.009 \\
\hline & & Sigma (2-tailed) & 0.133 & 0.797 & 0.513 & 0.865 \\
\hline \multirow{2}{*}{ Medium (51 and above) $n=124$} & \multirow[t]{2}{*}{ EG } & Pearson correlation & -0.140 & $-0.235^{*}$ & $-0.229 *$ & 0.027 \\
\hline & & Sigma (2-tailed) & 0.164 & 0.018 & 0.022 & 0.793 \\
\hline
\end{tabular}

*, Correlation is significant at the 0.05 level (2-tailed sigma).

SMME, small, medium and micro-enterprises; RT, risk-taking; PA-INNV, proactiveness-innovativeness; CA, competitive aggressiveness; AN, autonomy; EG, employment growth 
Moreover, considering the variation in findings between the entire SMME cohort and MSBs, two final models are presented in Figures 2 and 3.

Figure 2 shows the theoretical model for the entire sample of SMMEs, and the relationship between the environment and EO dimensions is depicted. Environmental dynamism and hostility are shown as the predictor variables and the four dimensions of EO (PA-INNV, RT, CA and AN) as the outcome variables. As found for the entire sample, statistical results do not support the relationships between any of the dimensions of EO and EG, so these relationships do not feature in the model.

Figure 3 shows another theoretical model for the study's cohort of MSBs. It is representative of a subset of the entire sample of the studied small businesses and consists of 124 businesses. In the second model the relationships between the environment, EO dimensions and EG are illustrated. Environmental dynamism and hostility are shown as the predictor variables, and the four dimensions of EO are presented as outcome variables. It is noteworthy that two of the dimensions of $\mathrm{EO}$, being proactive-innovation and CA, are shown to be associated with EG.

\section{Conclusion}

Within the context of this study, the environment was found to be a motivating factor for entrepreneurial behaviour amongst SMMEs. Indeed, the business environment in terms of its dynamism and hostility influences all dimensions of firm-level EO. As the relationships hypothesised between ED and EH and PA-INNV, RT, CA and AN were statistically significant in the positive direction, it implies that increased ED and EH can be related to higher entrepreneurial behaviour.

Concerning the relationship between EO dimensions and EG, the study shows that PA-INNV and CA reflect statistically significant associations with EG within MSBs. Hence, $H_{3 \& 6}$ and $H_{12}$ are remarkable, albeit only the latter finds support amongst

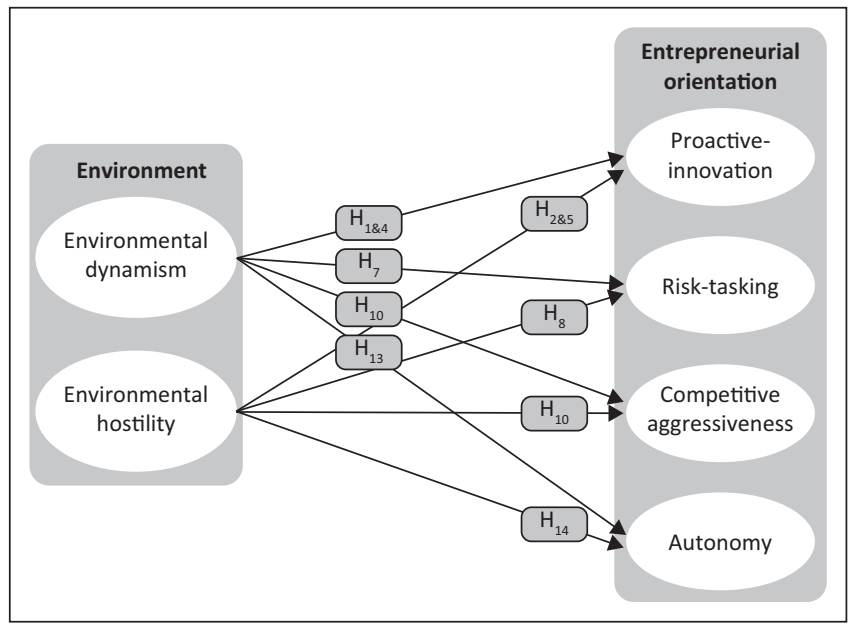

FIGURE 2: Theoretical model for the nexus between environment and entrepreneurial orientation for SMMEs.
MSBs. Therefore, this finding provides credence to the position that EG in relation to a firm's EO amongst SMMEs may be subject to size-dependent idiosyncrasies. In essence, a blanket model that attempts to link the components of EO to EG, given its insensitivity to the size of the businesses, may not suffice. This is likely to be the case as the extent of the quest for EG may differ between micro, small and medium-sized businesses. Also, as observed in this study, the relationship between the EO dimensions of PA-INNV and CA and the outcome variable of EG within MSBs is negative.

Whilst rational thinking may suggest that SMMEs that are proactively innovative and not risk-averse could record EG, this may not always be the case. As indicated by the findings, an orientation towards PA-INNV and CA may result in negative EG because growth in employees is not necessarily the primary motivation for such entrepreneurial actions. Small, medium and micro-enterprises may become proactive, innovative or competitively aggressive primarily to enhance business performance or increase efficiency levels. Indeed, higher levels of efficiency are often attained by reducing the extent to which resources are utilised for the achievement of set goals. In the case of an MSB, this may entail utilising the same employee-complement to achieve higher business goals. Against this background, it becomes plausible to appreciate that an increase of entrepreneurial intensity along the dimensions of PA-INNV and CA could be related to reduced rather than increased EG. In fact, increased innovation on the part of MSBs may be driven by the desire to boost performance by automating processes and reducing human interference, which in turn may actually lead to a reduction rather than an increase in employee numbers.

\section{Limitations and future research avenues}

The resource-based view and the dynamic capabilities perspective have largely informed the constructs examined for this study. Hence, the interplay between the business environment, EO and EG is yet to be thoroughly investigated through other theoretical lenses such as the

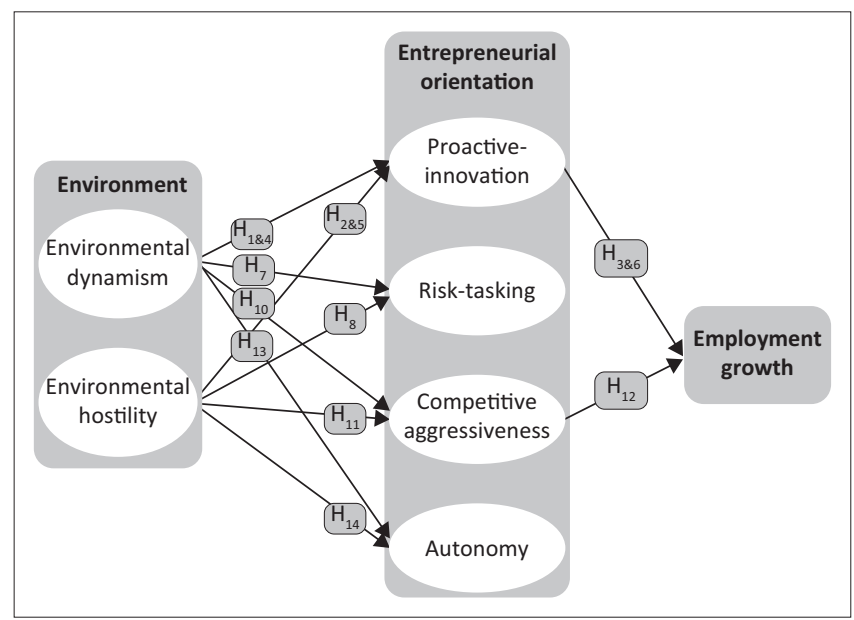

FIGURE 3: Theoretical model for the nexus of environment, entrepreneurial orientation and employment growth for MSBs. 
institutional theory. Future studies could explore this theoretical perspective, particularly in South Africa and countries of similar socioeconomic features where governmental and non-governmental institutions play significant roles in entrepreneurship and small business development. Indeed, these organisations play active roles in policy formulation, along with implementation and entrepreneurial finance.

In this study only two environmental variables (dynamism and hostility) have been examined. Future studies could consider other variables, environmental complexity, environmental munificence and environmental turbulence, as this will further illuminate the relationship between the environment and EO. Similarly, according to Huang, Pickernell, Battisti, Soetanto and Huang (2020), EO can be labelled as an exploratory orientation that entails uncertain returns. In fact, Lumpkin and Pidduck (2021, p. 17) recently directed attention towards plausibility of an EO theory. Therefore, researchers (Covin \& Wales, 2019, p. 3; Patel, Kohtamaki, Parida, \& Wincent, 2015, p. 1739) have called for studies to investigate potential factors that might counterbalance or complement EO to enhance organisational outcomes, for example EG in direct relation to this study. Moreover, the finding that PA and INNV are indistinguishable should be investigated to either corroborate or refute this study's observation. This would further enhance the understanding of entrepreneurial behaviour amongst businesses. It is notable that the relationship between the dimensions of EO and EG was not evident in this study, until the size of the business was considered, and the linkage between these variables was revealed amongst MSBs exclusively. Hence, MSBs may offer prospects in better understanding employment generation by businesses. Subsequently, research focus should be directed towards this category of small businesses.

\section{Acknowledgements}

The authors wish to appreciate the input of entrepreneurs and small business owners across South Africa, who responded to this study. In addition, the authors would also like to acknowledge the Department of Business Management, University of Pretoria, for the moral and financial support provided to actualise this study.

\section{Competing interests}

The authors declare that they have no financial or personal relationships that may have inappropriately influenced them in writing this article.

\section{Authors' contributions}

This research was jointly conceptualised, and all the authors, O.J.D., M.M., C.E-E., contributed equally to this work.

\section{Ethical considerations}

This article followed all ethical standards for research, and clearance was obtained from the Research Ethics Committee of the University of Pretoria.

\section{Funding information}

This research received no specific grant from any funding agency in the public, commercial or not-for-profit sectors.

\section{Data availability}

The authors confirm that the data supporting the findings of this study are available within the article.

\section{Disclaimer}

The views expressed in this article are those of the authors and do not necessarily reflect the official policy or position of the institution to which they are affiliated.

\section{References}

Ahmed, F.U., \& Brennan, L. (2019). Performance determinants of early internationalizing firms: The role of international entrepreneurial orientation Journal of International Entrepreneurship, 17(3), 389-424. https://doi. org/10.1007/s10843-019-00250-7

Alexandrova, M. (2004). Entrepreneurship in a transition economy: The impact of environment on entrepreneurial orientation. Problems and Perspectives in Management, 2(2), 140-148.

Altinay, L., Madanoglu, M., De Vita, G., Arasli, H., \& Ekinci, Y. (2016). The interface between organizational learning capability, entrepreneurial orientation and SME growth. Journal of Small Business Management, 54(3), 871-891. https://doi. org/10.1111/jsbm.12219

Al-Mamary, Y.H., Alwaheeb, M.A., Alshammari, N.G.M., Abdulrab, M., Balhareth, H., \& Soltane, H.B. (2020). The effects of entrepreneurial orienation in financial and non-fiannacial perforamnce in Saudi SMEs: A review. Journal of Critical Reviews, 7(4), 200-208

Anderson, B.S., Kreiser, P.M., Kuratko, D.F., Hornsby, J.S., \& Eshima, Y. (2015). Reconceptualizing entrepreneurial orientation. Strategic Management Journal, 36(10), 1579-1596. https://doi.org/10.1002/smj.2298

Bogatyreva, K., Beliaeva, T., Shirokova, G. \& Puffer, S.M. (2017). As different as chalk and cheese? The relationship between entrepreneurial orientation and SMEs growth: Evidence from Russia and Finland. Journal of East-West Business, 23(4) 337-366. https://doi.org/10.1080/10669868.2017.1345819

Bratnicka, K. (2014). Strategic entrepreneurship and firm performance - Restoring the role of the task environment. Research Papers of Wroclaw University of Economics No. 366: 59-67. Wroclaw.

Brock, D.M. (2003). Autonomy of individuals and organizations: Towards a strategy research agenda. International Journal of Business and Economics, 2(1), 57-73.

Carvalho, C.E., Rossetto, C.R., \& Piekas, A.A.A. (2021). Innovativness in Brazillian startups: The efect of absorptive capacity and environmental dynamism. International Journal of Learning and Innovation, 29(1), 1-17. https://doi. org/10.1504/IJIL.2021.10033583

Cassia, L., \& Minola, T. (2012). Hyper-growth of SMEs: Towards a reconciliation of entrepreneurial orientation and strategic resources. International Journal of Entrepreneurial Behaviour and Research, 18(2), 179-197. https://doi. org $/ 10.1108 / 13552551211204210$

Casillas, J.C. \& Moreno, A.M. (2010). The relationship between entrepreneurial orientation and growth: The moderating role of family involvement. Entrepreneurship and Regional Development, 22(3-4), 265-291. https://doi. org/10.1080/08985621003726135

Casillas, J.C., Moreno, A.M., \& Barbero, J.L. (2010). A configurational approach of the relationship between entrepreneurial orientation and growth of family firms. FamilyBusiness Review, 23(1),27-44. https://doi.org/10.1177/0894486509345159

Cooper, D.R., \& Schindler, P.S. (2014). Business research methods (12th edn.). New York, NY: McGraw-Hill.

Coad, A., Segarra, A., \& Teruel, M. (2016). Innovation and firm growth. Does firm age play a role? Research Policy, 45(2), 387-400. https://doi.org/10.1016/j. respol.2015.10.015

Covin, J.G., Green, K.M., \& Slevin, D.P. (2006). Strategic process effects on the entrepreneurial orientation-sales growth rate relationship. Entrepreneurial Theory and Practice, 30(1), 57-81. https://doi.org/10.1111/j.1540-6520.2006.00110.x

Covin, J.G., \& Slevin, D.P. (1989). Strategic management of small firms in hostile and benign environments. Strategic Management Journal, 10(1), 75-87. https://doi. org/10.1002/smj.4250100107

Covin, J.G., \& Wales, W.J. (2019). Crafting high-impact entrepreneurial orientation research: Some suggested guidelines. Entrepreneurship Theory and Practice, 43(1), 3-18. https://doi.org/10.1177/1042258718773181

Dachs, B., \& Peters, B. (2014). Innovation, employment growth and foreign ownership of firms. A European perspective. Research Policy, 43(1), 214-232. https://doi. org/10.1016/j.respol.2013.08.001 
Dele-ljagbulu, O.J., Eresia-Eke, C.E., \& Moos, M.N. (2020). Dimensions of firm-level entrepreneurial orientation as antecedents of employment growth in SMMEs. African Journal of Business and Economic Research, 15(3), 89-111. https://doi. org/10.31920/1750-4562/2020/v15n3a4

Eresia-Eke, C.E., Dele-ljagbulu, O.J., \& Moos, M.N. (2019). The Nexus of environmental dynamism and the dimensions of entrepreneurial orientation. Academy of Entrepreneurship Journal, 25(4), 1-12.

Fairoz, F.M., \& Hirobumi, T. (2016). Entrepreneurial orientation and business performance of small and medium scale enterprises in Japan. Asian Journal of Management Science and Education, 5(3), 64-70.

Farinha, L., Ferreira, J.J.M., \& Nunes, S. (2018). Linking innovation and entrepreneurship to economic growth. Competitiveness Review: An International Business Journal, 28(4), 451-475. https://doi.org/10.1108/CR-07-2016-0045

Futterer, F., Schmidt, J., \& Heidenreich, S. (2018). Effectuation or causation as the key to corporate venture success? Investigating effects of entrepreneurial behaviours on business model innovation and venture performance. Long Range Planning, 51(1), 64-81. https://doi.org/10.1016/j.Irp.2017.06.008

Gilley, K.M., Walters, B.A., \& Olson, B.J. (2002). Top management team risk-taking propensities and firm performance: Direct and moderating effects. Journal of Business Strategies, 19(2), 95-114.

Gibrat, R. (1931). Les Inégalités Économiques. Paris: Recueil Sirey.

Goll, I., \& Rasheed, A. (1997). Rational decision-making and firm performance. The moderating role of environment. Strategic Management Journal, 18(7), 583-591. https://doi.org/10.1002/(SICI)1097-0266(199708)18:7\%3C583::AID SMJ907\%3E3.0.CO;2-Z

Huang, S., Pickernell, D., Battisti, M., Soetanto, D., \& Huang, Q. (2020). When is entrepreneurial orientation beneficial for new product performance ? The roles of ambidexterity and market turbulence. International Journal of Entrepreneurial Behaviour and Research, 27(1), 79-98. https://doi.org/10.1108/ IJEBR-02-2020-01031355-2554

Hughes, M., \& Morgan, R.E. (2007). Deconstructing the relationship between entrepreneurial orientation and business performance at the embryonic stage of firm growth. Industrial Marketing Management, 36(5), 651-661.

Khedhaouria, A., Gurau, C., \& Torres, O. (2015). Creativity, self-efficacy and small-firm performance: The mediating role of entrepreneurial orientation. Small Business Economics, 44(3), 485-504.

Kreiser, P.M., \& Davis, J. (2010). Entrepreneurial orientation and firm performance: The unique impact of innovativeness, pro activeness and risk-taking. Journal of Small Business and Entrepreneurship, 23(1), 39-51. https://doi.org/10.1080/0827 6331.2010.10593472

Kreiser, P.M., Anderson, B.S., Kuratko, D.F. \& Marino, L.D. (2020). Entrepreneurial orientation and environmental hostility: A threat rigidity perspective. Entrepreneurship Theory and Practice, 44(6), 1174-1198.

Kusumawardhani, A., McCarthy, G., \& Perera, N. (2009). Framework of entrepreneurial orientation and networking: A study of SMEs performance in a developing country. Proceedings of the Australian and New Zealand Academy of Management Conference, Adelaide, pp. 1-16.

Le Roux, I., \& Bengesi, K.M.K. (2014). Dimensions of entrepreneurial orientation and small and medium enterprise performance in emerging economies. Development Southern Africa, 31(4), 606-624. https://doi.org/10.1080/0376835X.2014.913474

Lotz, H.M., \& Van der Merwe, S.P. (2013). An investigation of the influence of entrepreneurial orientation on the perceived success of agribusinesses in South Africa. South African Journal of Business Management, 44(1), 15-32. https://doi. org/10.4102/sajbm.v44i1.145

Li, H., \& Atuahene-Gima, K. (2001). Product innovation strategy and the performance of new technology ventures in China. Academy of Management Journal, 44(6), 1123-1134. https://doi.org/10.2307/3069392

Lumpkin, G.T., Cogliser, C.C., \& Schneider, D.R. (2009). Understanding and measuring autonomy: An entrepreneurial orientation perspective. Entrepreneurship Theory and Practice, 33(1), 47-69. https://doi.org/10.1111/j.1540-6520.2008.00280.x

Lumpkin, G.T., \& Dess, G.G. (1996). Clarifying the entrepreneurial orientation construct and linking it to performance. Academy of Management Review, 21(1), 135-172. https://doi.org/10.5465/amr.1996.9602161568

Lumpkin, G.T., \& Dess, G.G. (2001). Linking two dimensions of entrepreneurial orientation to firm performance: The moderating role of environment and industry life cycle. Journal of Business Venturing, 16(5), 429-451. https://doi. industry life cycle. Journal of Business
org/10.1016/S0883-9026(00)00048-3

Lumpkin, G.T., \& Pidduck, R.J. (2021). Global entrepreneurial orientation (GEO): An updated, multidimentional view to EO. In A.C. Corbett, P.M. Kreiser, L.D. Marino, \& W.J. Wales (Eds.), Entrepreneurial orienation: Epistemological theoretical, and empirical perspectives advances in entrepreneurship, firm emergence and growth, empirical perspectives advances in entrepreneurs
(pp. 17-68). Emerald Publishing Limited, Bingley.

Martens, C.D.P., Lacerda, F.M., Belfort, A.C., \& Freitas, H.M.R.D. (2016). Research on entrepreneurial orientation: Current status and future agenda. International Journal of Entrepreneurial Behavior and Research, 22(4), 556-583. https://doi. org/10.1108/IJEBR-08-2015-0183

Matchaba-Hove, T.M. \& Goliath, J.E. (2016). The entrepreneurial orientation and business performance relationship: A study of young adult-owned small business. Proceedings of the 28th Annual Conference of the Southern African Institute of Management Scientists, pp. 498-511, Pretoria, South Africa.

Maziti, L., Chinyamurindi, W., \& Marange, C. (2018). The relationship between strategic leadership, innovatiion performance, and competitive advanatge amonsgt a smaple of small businesses in South Africa. Journal of Contemporary Management, 15(1), 368-394.
McCarthy, D.J., Puffer, S.M., \& Lamin, A. (2018). Entrepreneurial orientation in a hostile and turbulent environment: Risk and innovativeness among successful Russian entrepreneurs. European Journal of International Management, 12(1/2), 191-220. https://doi.org/10.1504/EJIM.2018.089033

Meyer, N., \& Hamilton, L. (2020). Female entrepreneurs business traning and its effects on various entrepreneurial factors: Evidence from a developing country. International Journal of Economics and Finances Studies, 12(1), 135-151. https:// doi.org/10.34109/ijefs.202012109

Miller, D. (1983). The correlates of entrepreneurship in three types of firms. Management Science, 29(7), 770-791. https://doi.org/10.1287/mnsc.29.7.770

Miller, D., \& Friesen, P.H. (1982). Innovation in conservative and entrepreneurial firms. Two models of strategic momentum. Strategic Management Journal, 3(1), 1-25. https://doi.org/10.1002/smj.4250030102

Miller, D., \& Friesen, P.H. (1983). Strategy-making and environment: The third link. Strategic Management Journal, 4(3), 221-235. https://doi.org/10.1002/ smj.4250040304

Moreno, A.M., \& Casillas, J.C. (2007). High-growth SMEs versus non-high growth SMEs: A discriminate analysis. Entrepreneurship and Regional Development, 19(1), 69-88. https://doi.org/10.1080/08985620601002162

Moreno, A.M., \& Casillas, J.C. (2008). Entrepreneurial orientation and the growth of SMEs: A causal model. Entrepreneurship Theory \& Practice, 32(3), 507-528. https://doi.org/10.1111/j.1540-6520.2008.00238.x

Morris, M.H., Kuratko, D.F., \& Covin, J.G. (2008). Corporate entrepreneurship and innovation; entrepreneurial development within organisations. Mason $\mathrm{OH}$ : SouthWestern College Publishers.

Musara, M., Mabila, T., Gwaindepi, C., \& Netsai, D.L. (2020). Entrepreneurial activity for economic growth and unemployment reduction in South Africa. International Journal of Entrepreneurship, 24(2), 1-8.

Nadkarni, S., Chen, T., \& Chen, J. (2016). The clock is ticking ! Executive temporal depth, industry velocity and competitive aggressiveness. Strategic Management Journal, 37(6), 1132-1153. https://doi.org/10.1002/smj.2376

Naldi, L., Nordqvist, M., Sjoberg, K., \& Wiklund, J. (2007). Entrepreneurial orientation risk-taking and performance in family firms. Family Business Review, 20(1), 33-47. https://doi.org/10.1111/j.1741-6248.2007.00082.x

Neneh, B.N., \& Van Zyl, J. (2017). Entrepreneurial orientation and its impact on firm growth amongst SMEs in South Africa. Problems and Perspectives in Management, 15(3), 166-178. https://doi.org/10.21511/ppm.15(3).2017.14

Pallant, J. (2011). SPSS Survival Manual. A step by step guide to data analysis using SPSS (4th edn.). Allen \& Uumin. Crows Nest, New South Wales (NSW).

Patel, P.C., Kohtamaki, M., Parida, V., \& Wincent, J. (2015). Entrepreneurial orientationas experimentation and firm performance: The enabling role of absorptive capacity, Strategic Management Journal 36(11), 1739-1749. https://doi. org/10.1002/smj.2310

Prajogo, D.I. (2016). The strategic fit between innovation strategies and business environment in delivering business performance. International Journal of Production Economics 171(Pert 2), 241-249. https://doi.org/10.1016/j. ijpe.2015.07.037

Rauch, A., Wiklund, J., Lumpkin, G.T., \& Frese, M. (2009). Entrepreneurial orientation and business performance: An assessment of past research and suggestions for the future. Entrepreneurship Theory and Practice, 33(3), 761-787. https://doi. org/10.1111/j.1540-6520.2009.00308.x

Richard, O.C., Wu, J., Markocy, L.A., \& Chung, Y. (2019). Top management team demographic faultline strength and strategic change: What role does environmental dynamism play. Strategic Managment Journal, 40(6), 987-1009. environmental dynamism play. Stratt
https://doi.org/10.1002/smj.3009

Rodrigo-Alarcon, J., Gracia-Villaverde, P.M., Parra-Requena, G., \& Ruiz-Ortgea, M.J. (2017). Innovativeness in the context of technological and market dynamism: The conflicting effects of network density. Journal of Organizational Change conflicting effects of network density. Journal of Organizational Change
Management, 30(4), 548-568. https://doi.org/10.1108/JOCM-04-2016-0068

Rosenbusch, N., Rauch, A., \& Bausch, A. (2013). The mediating role of entrepreneurial orientation in the task environment-performance relationship: A meta-analysis. Journal of Management, 39(3), 633-659. relationship: A meta-analysis. Journal of Mar
https://doi.org/10.1177/0149206311425612

Singer, S., Amorós, J.E., Arreola, D.M., \& Global Entrepreneurship Research Association (GERA). (2015). Global entrepreneurship monitor 2014 global report. GERA. London: London Business School.

Slevin, D.P., \& Covin, J.G. (1997). Strategy formation patterns, performance and the significance of context. Journal of Management, 23(2), 189-209. https://doi. org/10.1177/014920639702300205

Soininen, J., Martikainen, M., Puumalainen, K., \& Kyläheiko, K. (2012). Entrepreneurial orientation: Growth and profitability of Finnish small and medium-sized enterprises. International Journal of Production Economics, 140(2), 614-621. https://doi.org/10.1016/j.ijpe.2011.05.029

Shafaeddin, M. (2012). Competitiveness and development: Myth and realities. New York, NY: Anthem Press.

Shirokova, G., Bogatyreva, K., Beliaeva, T., \& Puffer, S. (2016). Entrepreneurial orientation and firm performance in differential environmental settings. Contingency and configurational approaches. Journal of Small Business and Contingency and configurational approaches. Journal of Small Business and
Enterprise Development, 23(3), 703-727. https://doi.org/10.1108/ Enterprise Developm

Statistics South Africa. (2020). Quarterly labour force survey. Quarter 3: 2020. Statistic Release P0211. Pretoria: Department of Statistics Pretoria. 
Stenholm, P., Pukkinen, T., \& Heinonen, J. (2016). Firm growth in family business- the role of entrepreneurial orientation and the entrepreneurial activity. Journal of
Small Business Management, 54(2), 697-713. https://doi.org/10.1111/ jsbm.12166

Wales, W.J. (2016). Entrepreneurial orientation: A review and synthesis of promising research directions. International Small Business Journal, 34(1), 3-15. https://doi. org/10.1177/0266242615613840
Wiklund, J., \& Shepherd, D. (2005). Entrepreneurial orientation and small business performance: A configurational approach. Journal of Business Venturing, 20(1) 71-91. https://doi.org/10.1016/j.jbusvent.2004.01.001

Yang, Y., \& Ju, X. (2018). Evolution paths of start-ups and large firms' entrepreneurial orientation: Combination of proactiveness and competitive agressiveness. Advances in Economic, Business and Management Research, 54, 126-131. 